OPEN ACCESS

Edited by:

Hussain Gadelkarim Ahmed, University of Hail, Saudi Arabia

Reviewed by: Shuji Ogino,

Dana-Farber Cancer Institute, United States

Ibrahim Abdelmageed Ginawi, Ministry of Health, Saudi Arabia

*Correspondence:

Aida Santaolalla

aida.santaolalla@kcl.ac.uk

†These authors have contributed equally to this work

Specialty section

This article was submitted to Cancer Epidemiology and Prevention, a section of the journal Frontiers in Oncology

Received: 01 November 2019 Accepted: 14 February 2020

Published: 28 February 2020

Citation:

Sollie S, Santaolalla A, Michaud DS,

Sarker D, Karagiannis SN, Josephs DH, Hammar N, Walldius G, Garmo H, Holmberg L, Jungner I and

Van Hemelrijck M (2020) Serum Immunoglobulin G Is Associated With Decreased Risk of Pancreatic Cancer in the Swedish AMORIS Study. Front. Oncol. 10:263. doi: 10.3389/fonc.2020.00263

\section{Serum Immunoglobulin G Is Associated With Decreased Risk of Pancreatic Cancer in the Swedish AMORIS Study}

\author{
Sam Sollie ${ }^{1 t}$, Aida Santaolalla ${ }^{1 * t}$, Dominique S. Michaud ${ }^{2,3}$, Debashis Sarker ${ }^{1,4}$, \\ Sophia N. Karagiannis ${ }^{5}$, Debra H. Josephs ${ }^{1,4}$, Niklas Hammar ${ }^{6}$, Goran Walldius ${ }^{7}$, \\ Hans Garmo ${ }^{1}$, Lars Holmberg ${ }^{1}$, Ingmar Jungner ${ }^{8}$ and Mieke Van Hemelrijck ${ }^{1,6}$ \\ ${ }^{1}$ Translational Oncology \& Urology Research (TOUR), School of Cancer and Pharmaceutical Sciences, King's College \\ London, London, United Kingdom, ${ }^{2}$ Department of Public Health and Community Medicine, Tufts University School of \\ Medicine, Boston, MA, United States, ${ }^{3}$ Department of Epidemiology, Brown University School of Public Health, Providence, \\ RI, United States, ${ }^{4}$ Department of Medical Oncology, Guy's and St Thomas' NHS Trust, London, United Kingdom, ${ }^{5}$ St John's \\ Institute of Dermatology, School of Basic and Medical Biosciences, King's College London, Guy's Hospital, London, \\ United Kingdom, ${ }^{6}$ Unit of Epidemiology, Institute of Environmental Medicine, Karolinska Institutet, Stockholm, Sweden, ${ }^{7}$ Unit \\ of Cardiovascular Epidemiology, Institute of Environmental Medicine, Karolinska Institutet, Stockholm, Sweden, ${ }^{8}$ Clinical \\ Epidemiological Unit, Department of Medicine, Karolinska Institutet and CALAB Research, Stockholm, Sweden
}

Background: Emerging evidence points to potential roles of the humoral immune responses in the development of pancreatic cancer. Epidemiological studies have suggested involvement of viral and bacterial infections in pancreatic carcinogenesis. Experimental studies have reported high expression levels of antigens in pancreatic cancer cells. Therefore, we aimed to investigate the role of different components of humoral immunity in the context of pancreatic cancer. We evaluated associations between pre-diagnostic serum markers of the overall humoral immune system [immunoglobulin A ( $(\mathrm{g} A)$, immunoglobulin $\mathrm{G}(\mathrm{lgG})$ and immunoglobulin $\mathrm{M}(\mathrm{lg} \mathrm{M})$ ], and the risk of pancreatic cancer in the Swedish Apolipoprotein-related MORtality RISk (AMORIS) study.

Methods: We selected all participants ( $\geq 20$ years old) with baseline measurements of IgA, IgG or IgM ( $n=41,900,136,221$, and 29,919, respectively). Participants were excluded if they had a history of chronic pancreatitis and individuals were free from pancreatic cancer at baseline. Multivariate Cox proportional hazards regression was used to estimate risk of pancreatic cancer for medical cut-offs of lgA, IgG, and IgM.

Results: Compared to the reference level of 6.10-14.99 g/L, risk of pancreatic cancer was elevated among those with lgG levels $<6.10 \mathrm{~g} / \mathrm{L}$ [HR: 1.69 (95\% Cl 0.99-2.87)], and an inverse association was observed among those with lgG levels $\geq 15.00 \mathrm{~g} / \mathrm{L}[0.82$ (95\% $\mathrm{Cl}$ 0.64-1.05); Ptrend $=0.027]$. The association appeared to be stronger for women than men [HR: 0.64 (95\% Cl 0.43-0.97) and 0.95 (95\% Cl 0.69-1.29), respectively]. No associations were observed with IgA or IgM.

Conclusion: An inverse association was observed between pre-diagnostic serum levels of $\operatorname{lgG}$ and risk of pancreatic cancer. Our findings highlight the need to further investigate the role of immune response in pancreatic cancer etiology.

\footnotetext{
Keywords: serum immunoglobulin, pancreatic cancer, IgA, IgG, IgM, immune system and cancer, AMORIS
} 


\section{INTRODUCTION}

Pancreatic cancer is predicted to be the second leading cause of cancer-related death by 2030 (1), and is frequently diagnosed at an advanced stage. To date, the etiology of pancreatic cancer is not well understood (2). Apart from smoking (3), long-standing diabetes (4), obesity and chronic pancreatitis (5), little is known about the risk factors and biological processes that lead to pancreatic cancer development $(6,7)$.

Recently, there has been mounting evidence that the humoral immune system plays a role in the development of pancreatic cancer. Epidemiological studies have suggested that viral and bacterial infections contribute to pancreatic cancer pathogenesis (8-13). Most studies focused on humoral responses to Helicobacter pylori and found contradicting results (1417). More recently, periodontal disease, caused by bacterial infections of pathogens such as Porphyromonas gingivalis and Fusobacterium species, has been suggested to play a role in the development and prognosis of pancreatic cancer (18-24). Furthermore, other responses of the humoral immune system, such as allergic reactions, may present a protective effect for pancreatic cancer diagnosis (25-29).

In addition to the epidemiological studies, experimental studies have reported a number of antigens that are highly expressed in pancreatic cancer cells $(30,31)$. For example, significant levels of immunoglobulin (Ig) G antibodies have been detected in cancer patients' plasma, including in pancreatic cancer patients. More specifically, anti-MUC1 serum IgG levels and IgG serum IgG4 concentrations ( $>135 \mathrm{mg} / \mathrm{dL}$ ) have been measured in patients with pancreatic cancer (32-34). In contrast, no data is available for other antibodies such as IgA and IgM in relation with pancreatic cancer.

Despite the growing evidence for a role of the humoral immune system in pancreatic cancer development, to our knowledge no epidemiological studies have yet evaluated the association between pre-diagnostic serum markers of the overall humoral immune response and risk of pancreatic cancer. A better understanding of the etiology and underlying biological mechanisms for pancreatic cancer may improve our ability to identify high risk individuals and improve early detection.

We therefore present the first large population-based prospective cohort study to examine pre-diagnostic markers of the overall humoral immune response (IgG, IgA, and IgM) in relation to pancreatic cancer.

\section{MATERIALS AND METHODS}

\section{Study Population and Data Collection}

The Swedish Apolipoprotein-related MORtality RISk (AMORIS) cohort includes information from blood and urine samples for 812,073 subjects obtained and analyzed between 1985 and 1996. All laboratory analyses were conducted at the Central Automation Laboratory (CALAB), Stockholm. The subjects were residents of Sweden and were predominantly living in the Stockholm county, ranging in age from less than 20 to over 80 years old. All participants were either healthy individuals referred for clinical laboratory testing as part of health check-ups or outpatients referred for laboratory testing (35). A more detailed description of the AMORIS cohort is given elsewhere (35-39).

The AMORIS cohort has been followed via record linkage using the Swedish 10-digit personal identity number in Swedish national health registers, registers of quality of care, and surveys including socio-economic data as well as a questionnaire and biomedical data from number of research cohorts (35). For the purpose of the current study, the National Cancer Register, the Patient Register, the Cause of death Register and the consecutive Swedish Censuses during 1970-1990 have been utilized. This study complied with the Declaration of Helsinki and was approved by the Ethics Review Board of the Karolinska Institutet.

This study included all individuals aged 20 years or older who were free from pancreatic cancer at baseline, as registered in the National Cancer Register dating back to 1958. Furthermore, participants were excluded if they had a history of chronic pancreatitis, as defined in the National Patient Register going back nationally to 1987 and regionally to 1964 . All subjects were required to have a baseline measurement of IgA or IgG or IgM measured at a health examination between 1985 and 1996. If a participant had multiple measurements of an immunoglobulin, the first measurement was included in the study to allow for consistency across the entire cohort. Follow-up time was defined as time from baseline measurement until date of cancer diagnosis, death, emigration, or end of the study (31st of December 2011), whichever occurred first.

The main outcome variable was a diagnosis of pancreatic cancer (International Classification of Diseases (ICD), Revision 7 (1955) code 157). We also included the following information from the AMORIS study: serum IgA $(\mathrm{g} / \mathrm{L})$, serum $\operatorname{IgG}(\mathrm{g} / \mathrm{L})$, serum $\operatorname{IgM}(\mathrm{g} / \mathrm{L})$, serum glucose $(\mathrm{mmol} / \mathrm{L})$, age at baseline measurement and gender. From the other registries, we collected information regarding education, Charlson Comorbidity Index (CCI) and socioeconomic status (SES).

The quantitative determination of $\operatorname{IgA}, \operatorname{IgG}$, and $\operatorname{IgM}$ was performed using turbidimetry with reagents (DAKO - Glostrup, Denmark) using a HITACHI 911 automatic analyser (Boehringer - Mannheim, Germany) with a coefficient of variation $<5 \%$ $(\operatorname{Ig} A), \leq 5 \%(\operatorname{IgG})$, and $\leq 7 \%(\operatorname{IgM})(40-42)$.

\section{Data Analyses}

We estimated the risk of pancreatic cancer with multivariate Cox proportional hazards regression for medical cut-offs used in the CALAB laboratory of IgG $(<6.10,6.10-14.99, \geq 15.00 \mathrm{~g} / \mathrm{L})(41)$. IgA was dichotomised as $<3.66 \mathrm{~g} / \mathrm{L}$ and $\geq 3.66 \mathrm{~g} / \mathrm{L}$ instead of the medical cut-offs $(<0.70,0.70-3.65, \geq 3.66 \mathrm{~g} / \mathrm{L})$ due to the small number of participants with low IgA levels $(40,43)$. Levels of IgM were dichotomised as $<1.40 \mathrm{~g} / \mathrm{L}$ and $\geq 1.40 \mathrm{~g} / \mathrm{L}$, as proposed by the normal laboratory values for blood, plasma and serum from the MSD manual (44).

Multivariate Cox proportional hazards regression models were adjusted for age, gender, education, CCI and serum glucose level (continuous variable). A test for trend was conducted by using assignment to medical cut-offs as an ordinal scale for IgG. To assess reverse causation, a sensitivity analysis was conducted in which those who had a follow-up time $<1$ year and $<3$ years, respectively, were removed. 
TABLE 1 | Descriptive statistics of study population with a measurement of lgG.

\begin{tabular}{|c|c|c|}
\hline & $\begin{array}{c}\text { Pancreatic cancer } \\
N=689 \\
n(\%)\end{array}$ & $\begin{array}{c}\text { No pancreatic cancer } \\
N=135,532 \\
n(\%)\end{array}$ \\
\hline Mean Age (years) (SD) & $55.8(11.37)$ & $47.1(14.33)$ \\
\hline$<55$ & $319(46.30)$ & $95,342(70.35)$ \\
\hline$\geq 55$ & $370(53.70)$ & $40,190(29.65)$ \\
\hline \multicolumn{3}{|l|}{ Gender } \\
\hline Men & $388(56.31)$ & $68,995(50.91)$ \\
\hline Women & $301(43.69)$ & $66,537(49.09)$ \\
\hline \multicolumn{3}{|l|}{ SES } \\
\hline Unclassified/missing & $74(10.74)$ & $13,561(10.01)$ \\
\hline Low & $283(41.07)$ & $59,611(43,98)$ \\
\hline High & $332(48.19)$ & $62,360(46.01)$ \\
\hline \multicolumn{3}{|l|}{ Education } \\
\hline Missing & $109(15.82)$ & $8,594(6.34)$ \\
\hline Low & $211(30.62)$ & $37,876(27.95)$ \\
\hline Middle & $241(34.98)$ & $55,617(41.04)$ \\
\hline High & $128(18.58)$ & $33,445(24.68)$ \\
\hline \multicolumn{3}{|l|}{ Charlson Comorbidity Index } \\
\hline 0 & $622(90.28)$ & $126,594(93.41)$ \\
\hline 1 & $49(7.11)$ & $6,265(4.62)$ \\
\hline 2 & $13(1.89)$ & $1,565(1.15)$ \\
\hline $3+$ & $5(0.73)$ & $1,108(0.82)$ \\
\hline Mean follow-up time (years) (SD) & $13.1(7.64)$ & $21.3(6.67)$ \\
\hline \multicolumn{3}{|l|}{ Glucose (mmol/L) } \\
\hline Mean (SD) & $5.34(1.71)$ & $5.01(1.28)$ \\
\hline$<5.60 \mathrm{mmol} / \mathrm{L}$ & $501(72.71)$ & $107,538(79.35)$ \\
\hline $5.60-6.99 \mathrm{mmol} / \mathrm{L}$ & $107(15.53)$ & $14,352(10.59)$ \\
\hline$\geq 7.00 \mathrm{mmol} / \mathrm{L}$ & $48(6.97)$ & 4,040 (2.98) \\
\hline Missing & $33(4.79)$ & $9,602(7.08)$ \\
\hline \multicolumn{3}{|l|}{$\lg G(g / L)$} \\
\hline Mean (SD) & $11.17(2.77)$ & $11.55(3.03)$ \\
\hline$<6.10 \mathrm{~g} / \mathrm{L}$ & $14(2.03)$ & $1,493(1.10)$ \\
\hline $6.10-14.99 \mathrm{~g} / \mathrm{L}$ & 601 (87.23) & $116,704(86.11)$ \\
\hline$\geq 15.00 \mathrm{~g} / \mathrm{L}$ & $74(10.74)$ & $17,335(12.79)$ \\
\hline
\end{tabular}

TABLE 2 | Hazard ratio (HR) for risk of pancreatic cancer, in the study population with a measurement of $\mathrm{lgG}$, with 95\% confidence intervals (Cl) using Cox proportional hazards model.

\begin{tabular}{lcc}
\hline & $\begin{array}{c}\text { Pancreatic cancer/total } \\
\boldsymbol{N}\end{array}$ & $\begin{array}{c}\text { Hazard ratio } \\
\mathbf{( 9 5 \% ~ C l )}\end{array}$ \\
\hline $\mathbf{I g G} \mathbf{( g / L )}$ & & \\
$<6.10 \mathrm{~g} / \mathrm{L}$ & $14 / 1,507$ & $1.69(0.99-2.87)$ \\
$6.10-14.99 \mathrm{~g} / \mathrm{L}$ & $601 / 117,305$ & $1.00($ ref $)$ \\
$\geq 15.00 \mathrm{~g} / \mathrm{L}$ & $74 / 17,409$ & $0.82(0.64-1.05)$ \\
$P$-value for trend & & 0.027 \\
\hline
\end{tabular}

${ }^{a}$ Adjusted for age, gender, education, $\mathrm{CCl}$, and serum glucose (continuous variable).

With regards to IgG, we performed stratified analyses for age $(<55$ and $\geq 55$ ), gender (male and female) and serum glucose levels $(<7.00$ and $\geq 7.00 \mathrm{mmol} / \mathrm{L})$. A $P$-value for interaction was calculated.
TABLE 3 | Hazard ratio (HR) for risk of pancreatic cancer stratified by gender, in the study population with a measurement of $\operatorname{lgG}$, with $95 \%$ confidence intervals from Cox proportional Hazards model.

\begin{tabular}{|c|c|c|}
\hline \multirow[b]{2}{*}{ Gender } & \multicolumn{2}{|c|}{ Hazard Ratio ${ }^{a}(95 \%$ Cl) } \\
\hline & Male & Female \\
\hline Pancreatic cancer/total (n) & $388 / 69,383$ & $301 / 66,838$ \\
\hline \multicolumn{3}{|l|}{$\lg G(g / L)$} \\
\hline$<6.10 \mathrm{~g} / \mathrm{L}$ & $1.46(0.65-3.27)$ & $1.98(0.97-4.00)$ \\
\hline $6.10-14.99 \mathrm{~g} / \mathrm{L}$ & 1.00 (ref) & 1.00 (ref) \\
\hline$\geq 15.00 \mathrm{~g} / \mathrm{L}$ & $0.95(0.69-1.29)$ & $0.64(0.43-0.97)$ \\
\hline$P$-value for interaction & \multicolumn{2}{|c|}{0.003} \\
\hline
\end{tabular}

${ }^{a}$ Adjusted for age, education, $\mathrm{CCl}$, and serum glucose (continuous variable).

Finally, restrictive Cubic Spline (RCS) function was used to graphically display the hazard ratios representing the doseresponse association between IgG and the risk of pancreatic cancer. We used knots located at the 5, 50, and 95th percentiles. This analysis was performed using the RCS_RegSAS Macro created by Desquibet and Mariotti (45). All statistical analyses were conducted with Statistical Analysis Systems (SAS) release 9.4 (SAS Institute, Cary, NC).

\section{RESULTS}

\section{Immunoglobulin G}

Characteristics of study participants with a measurement of $\operatorname{IgG}$ are shown in Table 1. During a mean follow-up of 21.3 years, 689 participants developed pancreatic cancer. The mean age at measurement in participants who later developed pancreatic cancer was higher (55.8 years) than in participants without pancreatic cancer (47.1 years).

Multivariate Cox regression (adjusted for age, gender, education, CCI, and serum glucose level) for the association between immunoglobulin $G$ and the risk of pancreatic cancer showed that, compared to the IgG reference level of 6.10-14.99 $\mathrm{g} / \mathrm{L}$, there was a positive association for those with IgG levels $<6.10 \mathrm{~g} / \mathrm{L}$ [HR: 1.69 (95\% CI 0.99-2.87)]. We also found an inverse association for those with $\operatorname{IgG}$ levels $\geq 15.00 \mathrm{~g} / \mathrm{L}[0.82$ (95\% CI 0.64-1.05); Ptrend $=0.027$ ] (Table 2). A sensitivity analysis to assess reverse causation by excluding those with follow-up time $<1$ year and $<3$ year did not affect the above findings (results not shown).

Stratified analysis by gender showed a similar inverse association between categories of IgG and the risk of developing pancreatic cancer. However, the strength of the association was more pronounced for women $(\mathrm{P}=0.003)$ (Table 3). No effect modification by age and glucose levels was observed (results not shown). We further illustrated the association between serum IgG and the risk of developing pancreatic cancer through a dose-response curve with restrictive cubic splines (Figure 1). The direction of the hazard ratios observed in Tables 2, 3 was consistent with shape of the curve, which presented a positive association for IgG levels lower than $11.00 \mathrm{~g} / \mathrm{L}$ with 


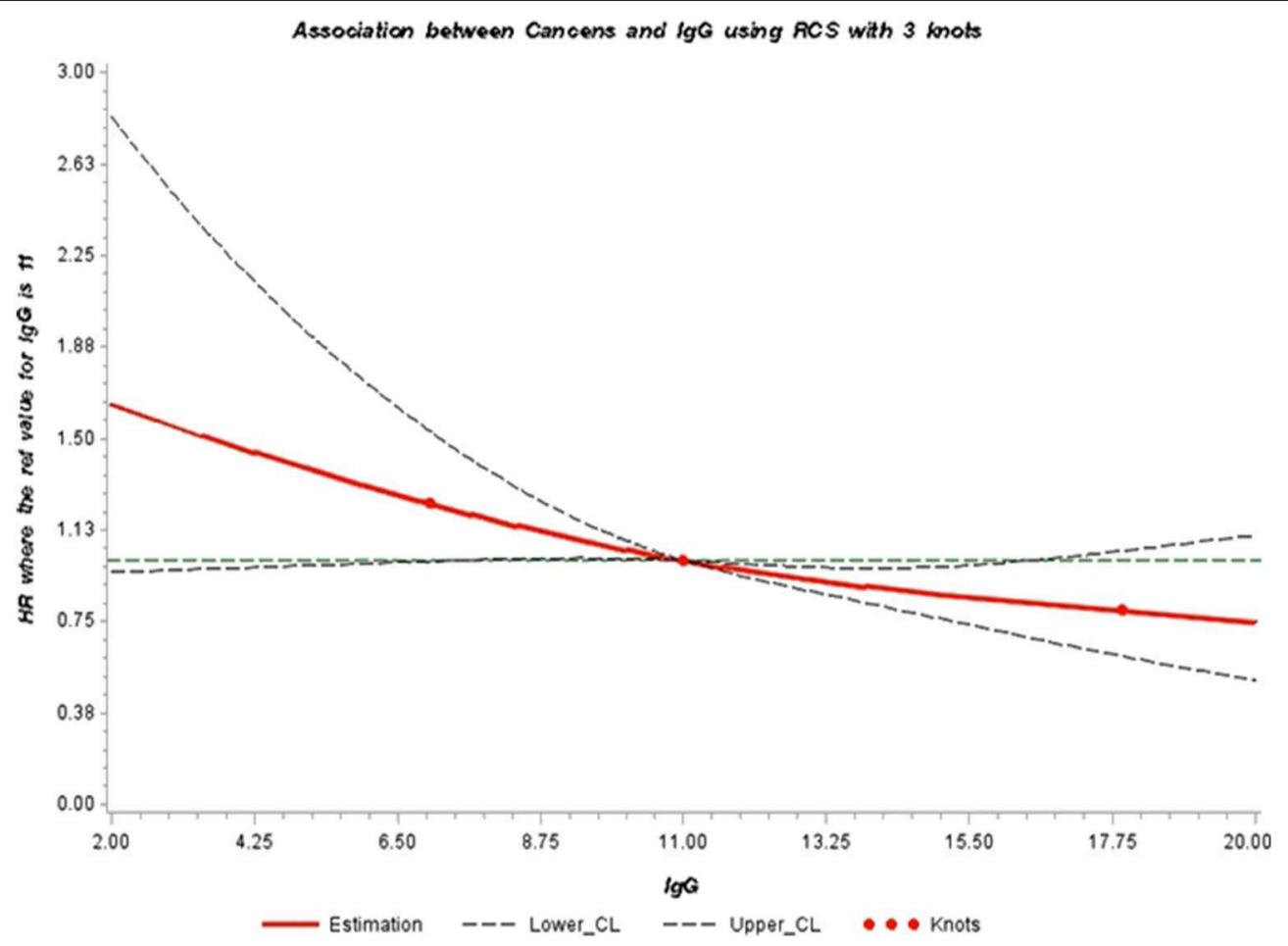

FIGURE 1 | Adjusted dose-response association between serum levels of $\operatorname{lgG}(\mathrm{g} / \mathrm{L})$ and risk of pancreatic cancer (HR) using restrictive cubic splines. The direction of the hazard ratios observed in Tables 2, 3 was consistent with the shape of the curve, which presents a positive association for lgG levels lower than $11.00 \mathrm{~g} / \mathrm{L}$ with pancreatic cancer risk ( $H R>1.00)$ and a protective effect for high levels of $\lg G(11.00-20.00 \mathrm{~g} / \mathrm{L})(\mathrm{HR}<1.00)$. However, the inverse association was only statistically significant for concentrations of IgG between 11.00 and $16.00 \mathrm{~g} / \mathrm{L}$.

pancreatic cancer risk and a protective effect for high levels of IgG (11.00-20.00 g/L).

\section{Immunoglobulin A and Immunoglobulin M}

Characteristics of study participants with a measurement of IgA are shown in Table 4. During a mean follow-up of 16.5 years, 169 participants developed pancreatic cancer. Characteristics of study participants with a measurement of $\operatorname{IgM}$ are shown in Table 5. During a mean follow-up of 15.4 years, 117 participants developed pancreatic cancer.

We found no association between immunoglobulin $A$ or immunoglobulin $\mathrm{M}$ and the risk of pancreatic cancer (Tables 6, 7).

\section{DISCUSSION}

In this project, we indicate the presence of an inverse association between serum IgG levels and the risk of developing pancreatic cancer in the Swedish AMORIS cohort. The inverse association was stronger in females compared with males. Pre-diagnostic serum levels of IgA or IgM did not show any association with the risk of pancreatic cancer.

The immune system has been thought to modulate the development and evolution of pancreatic cancer (46). Tobacco smoking, chronic pancreatitis, obesity and long-standing diabetes are established risk factors for pancreatic cancer
$(4,5,47,48)$. All these risk factors can influence the immune response, induce the formation of pre-malignant lesions and stimulate pancreatic cancer development (49, 50). Pancreatic cancer tissue contains multiple immunosuppressive cell types, suggesting an impairment of the immune response in the tumor micro-environment (50). Evidence is growing for the role of the tumor-infiltrating $\mathrm{B}$ cells in the initiation and progression of pancreatic cancer (51). Tanaka et al., among other groups, also identified high serum levels of $\operatorname{IgG}$ on advanced pancreatic patients indicating IgG as a potential diagnostic test for pancreatic cancer (52).

Recent experimental and epidemiological data suggest the importance of the microbiome in pancreatic cancer development and its potential use as a marker of disease susceptibility $(9,49$, $53,54)$. Kau et al. highlighted the close interplay between life-style factors, such as diet and nutritional status, with the microbial ecology in the humans digestive system and its modulation of the immune system (55). Moreover, there is increasing evidence of the influence of the microbiota in the development of human diseases such as obesity and diabetes, established risks factors for pancreatic cancer $(56,57)$. More specifically, exposure to the bacterium Helicobacter Pylori is suggested as a risk factor for pancreatic cancer (14-17). Data also suggest a positive association between periodontal disease, due to an infection of the periodontal bacterium Porphyromonas gingivalis and Fusobacterium species, and pancreatic cancer risk $(8,18-23)$. The 
TABLE 4 | Descriptive statistics of study population with a measurement of IgA.

\begin{tabular}{|c|c|c|}
\hline & $\begin{array}{c}\text { Pancreatic cancer } \\
N=169 \\
n(\%)\end{array}$ & $\begin{array}{c}\text { No pancreatic cancer } \\
N=41,731 \\
n(\%)\end{array}$ \\
\hline Mean Age (years) (SD) & $60.3(12.07)$ & $49.6(16.10)$ \\
\hline$<55$ & 58 (34.32) & $27,142(65.04)$ \\
\hline$\geq 55$ & $111(65.68)$ & $14,589(34.96)$ \\
\hline \multicolumn{3}{|l|}{ Gender } \\
\hline Men & $69(40.83)$ & 14,999 (35.94) \\
\hline Women & $100(59.17)$ & $26,732(64.06)$ \\
\hline \multicolumn{3}{|l|}{ SES } \\
\hline Unclassified/Missing & 27 (15.98) & 7,499 (17.97) \\
\hline Low & $69(40.83)$ & $18,137(43.46)$ \\
\hline High & $73(43.20)$ & $16,095(38.57)$ \\
\hline \multicolumn{3}{|l|}{ Education } \\
\hline Missing & $14(8.28)$ & $2,358(5.65)$ \\
\hline Low & 50 (29.59) & $10,787(25.85)$ \\
\hline Middle & $64(37.87)$ & $17,734(42.50)$ \\
\hline High & $41(24.26)$ & $10,852(26.00)$ \\
\hline \multicolumn{3}{|c|}{ Charlson Comorbidity Index } \\
\hline 0 & $138(81.66)$ & $37,290(89.36)$ \\
\hline 1 & $22(13.02)$ & $2,950(7.07)$ \\
\hline 2 & $7(4.14)$ & $856(2.05)$ \\
\hline $3+$ & $2(1.18)$ & $635(1.52)$ \\
\hline $\begin{array}{l}\text { Mean follow-up time } \\
\text { (years) (SD) }\end{array}$ & $8.8(5.88)$ & $16.5(5.22)$ \\
\hline \multicolumn{3}{|l|}{ Glucose (mmol/L) } \\
\hline Mean (SD) & $5.50(1.76)$ & $5.08(1.42)$ \\
\hline$<5.60 \mathrm{mmol} / \mathrm{L}$ & $96(56.80)$ & $25,481(61.06)$ \\
\hline $5.60-6.99 \mathrm{mmol} / \mathrm{L}$ & 25 (14.79) & $3,990(9.56)$ \\
\hline$\geq 7.00 \mathrm{mmol} / \mathrm{L}$ & $11(6.51)$ & $1,315(3.15)$ \\
\hline Missing & 37 (21.89) & 10,945 (26.23) \\
\hline \multicolumn{3}{|l|}{$\lg A(g / L)$} \\
\hline Mean (SD) & $2.47(1.20)$ & $2.32(1.20)$ \\
\hline$<3.66 \mathrm{~g} / \mathrm{L}$ & $151(89.35)$ & $37,228(89.21)$ \\
\hline$\geq 3.66 \mathrm{~g} / \mathrm{L}$ & $18(10.65)$ & 4,503 (10.79) \\
\hline
\end{tabular}

microbiota immune modulation promoting cancer pathogenesis has been explained through inflammatory processes in the tumor tissue, however it has also been shown in mice that bacteria not present in the tumorigenic tissue can promote carcinogenesis, nor do they need to cause inflammation in the tumor microenvironment $(8,58)$. New studies should further explore the interplay between lifestyle factors, microbiota and dysregulation of the immune system, which could provide new avenues to better understand the etiology of pancreatic cancer.

To our knowledge, this study is the first cohort that prospectively evaluate the association between pre-diagnostic serum markers of the overall humoral immune response and risk of pancreatic cancer. The observed inverse association between serum IgG and the risk of developing pancreatic cancer is consistent with the work by Michaud et al. (20): in a cluster analysis on oral bacteria antibodies, the cluster with overall higher levels of antibodies against 25 oral bacteria had a $45 \%$
TABLE 5 | Descriptive statistics of study population with a measurement of IgM.

\begin{tabular}{|c|c|c|}
\hline & $\begin{array}{c}\text { Pancreatic cancer } \\
N=117 \\
n(\%)\end{array}$ & $\begin{array}{c}\text { No pancreatic cancer } \\
\begin{array}{c}N=29,802 \\
n(\%)\end{array}\end{array}$ \\
\hline Mean Age (years) (SD) & $60.9(11.76)$ & $50.8(16.25)$ \\
\hline$<55$ & $36(30.77)$ & $18,613(62.46)$ \\
\hline$\geq 55$ & $81(69.23)$ & $11,189(37.54)$ \\
\hline \multicolumn{3}{|l|}{ Gender } \\
\hline Men & $48(41.03)$ & $10,852(36.41)$ \\
\hline Women & $69(58.97)$ & $18,950(63.59)$ \\
\hline \multicolumn{3}{|l|}{ SES } \\
\hline Unclassified/missing & $18(15.38)$ & $5,675(19.04)$ \\
\hline Low & $51(43.59)$ & $12,759(42.81)$ \\
\hline High & $48(41.03)$ & $11,368(38.15)$ \\
\hline \multicolumn{3}{|l|}{ Education } \\
\hline Missing & $8(6.84)$ & $1,658(5.56)$ \\
\hline Low & $37(31.62)$ & $7,885(26.46)$ \\
\hline Middle & $43(36.75)$ & $12,585(42.23)$ \\
\hline High & 29 (24.79) & $7,674(25,75)$ \\
\hline \multicolumn{3}{|c|}{ Charlson comorbidity index } \\
\hline 0 & $88(75.21)$ & $26,205(87.93)$ \\
\hline 1 & $20(17.09)$ & $2,349(7.88)$ \\
\hline 2 & $6(5.13)$ & $697(2.34)$ \\
\hline $3+$ & $3(2.56)$ & $551(1.85)$ \\
\hline $\begin{array}{l}\text { Mean follow-up time } \\
\text { (years) (SD) }\end{array}$ & $8.15(5.53)$ & $15.4(4.73)$ \\
\hline \multicolumn{3}{|l|}{ Glucose (mmol/L) } \\
\hline Mean (SD) & $5.53(1.59)$ & $5.19(1.51)$ \\
\hline$<5.60 \mathrm{mmol} / \mathrm{L}$ & $60(51.28)$ & $16,259(54.56)$ \\
\hline $5.60-6.99 \mathrm{mmol} / \mathrm{L}$ & $19(16.24)$ & $3,140(10.54)$ \\
\hline$\geq 7.00 \mathrm{mmol} / \mathrm{L}$ & $8(6.84)$ & $1,046(3.51)$ \\
\hline Missing & $30(25.64)$ & $9,357(31.40)$ \\
\hline \multicolumn{3}{|l|}{$\operatorname{IgM}(g / L)$} \\
\hline Mean (SD) & $1.11(0.72)$ & $1.28(0.96)$ \\
\hline$<1.40 \mathrm{~g} / \mathrm{L}$ & 90 (76.92) & 20,330 (68.22) \\
\hline$\geq 1.40 \mathrm{~g} / \mathrm{L}$ & 27 (23.08) & 9,472 (31.78) \\
\hline
\end{tabular}

TABLE 6 | Hazard ratio (HR) for risk of pancreatic cancer, in the study population with a measurement of IgA, with 95\% confidence intervals (Cl) using Cox proportional hazards model.

\begin{tabular}{lcc}
\hline & $\begin{array}{c}\text { Pancreatic cancer/total } \\
\boldsymbol{N}\end{array}$ & $\begin{array}{c}\text { Hazard ratio } \\
\mathbf{( 9 5 \% ~ C l )}\end{array}$ \\
\hline $\operatorname{lgA}(\mathbf{g} / \mathrm{L})$ & & \\
$<3.66 \mathrm{~g} / \mathrm{L}$ & $151 / 37,379$ & $1.00(\mathrm{ref})$ \\
$\geq 3.66 \mathrm{~g} / \mathrm{L}$ & $18 / 4,521$ & $0.70(0.39-1.26)$ \\
\hline
\end{tabular}

${ }^{a}$ Adjusted for age, education, $\mathrm{CCl}$, and serum glucose (continuous variable).

lower risk of pancreatic cancer development than a cluster with overall lower levels of antibodies. This finding suggest that higher levels of antibodies against oral bacteria may reflect a stronger immune status which could have beneficial impact on reducing the risk of pancreatic cancer (20). Moreover, experimental studies found a similar protective effect for increased levels of IgG. 
TABLE 7 | Hazard ratio (HR) for risk of pancreatic cancer, in the study population with a measurement of IgM, with 95\% confidence intervals (Cl) using Cox proportional hazards model.

\begin{tabular}{lcc}
\hline & Pancreatic cancer/total $\mathbf{N}$ & $\begin{array}{c}\text { Hazard ratio } \\
\mathbf{( 9 5 \% ~ C l )}\end{array}$ \\
\hline $\lg \mathbf{M}$ (g/L) & \\
$<1.40 \mathrm{~g} / \mathrm{L}$ & $90 / 20,420$ & 1.00 (ref) \\
$\geq 1.40 \mathrm{~g} / \mathrm{L}$ & $27 / 9499$ & $0.82(0.50-1.35)$ \\
\hline
\end{tabular}

${ }^{a}$ Adjusted for age, education, CCl, and serum glucose (continuous variable).

Hamanaka et al., found circulating IgG antibodies to be a favorable prognostic factor for pancreatic cancer (59). In a recent publication, Follia et al. presented novel metabolic subtypes in pancreatic cancer and observed that the high immune infiltrated tumors had a better prognosis (60).

Regarding the stronger inverse association observed between IgG levels and pancreatic cancer, presented in women in our study, we suggest that this may indicate that sex is an effect modifier in this association given the differential distribution of immunoglobulin levels between sex that has been described previously (43).

The Swedish AMORIS cohort is one of the largest prospective cohort studies with detailed information on a range of serum biomarkers, including large number of baseline measurements of serum markers of the humoral immune system, all measured at the same clinical laboratory (61) at baseline health examinations during the period 1985-1996. The cohort has a 30+ year followup in Swedish national registers, including the Cancer, Patient, Census and Cause-of-Death registers, as well as quality registers for specific cancer sites. All participants of the AMORIS study were included by analysing blood and/or urine samples from health check-ups in non-hospitalized persons (62). However, any healthy cohort effect would not affect the internal validity of our study. The external validity of the study is not compromised given that the cancer incidence in the AMORIS population is comparable to the reported incidence in the Swedish population (35).

It was a limitation that immunoglobulin $\mathrm{E}(\operatorname{IgE})$, a serum biomarker of allergies studied previously in relation with pancreatic cancer (63), was only measured for a small subset of participants, so that it could not be assessed in relation to risk of pancreatic cancer. In addition, repeated measurements would have been helpful to verify the lag time between changes in markers of the humoral immune system and risk of pancreatic cancer. However, most of the individuals did not have multiple measurements. Information on other possible confounders such as BMI and smoking status was not available on AMORIS, therefore all models were adjusted for Charlson Comorbidity Index as a proxy for lifestyle factors. Biological material was unfortunately not available for further analyses. Molecular pathological analyses, such as the presence of immune cell infiltrates on the tumor tissue samples, can be an important resource in future studies to explore the potential association of the immune system, microbiome, lifestyle factors and pancreatic cancer development and to validate the epidemiological findings.

\section{CONCLUSION}

To our knowledge, this study is the first prospective cohort study evaluating the association between pre-diagnostic serum markers of the overall humoral immune response and the risk of pancreatic cancer. We observed an inverse association between pre-diagnostic serum levels of IgG and the risk of pancreatic cancer. Our findings highlight the need to investigate the roles of different components of humoral immunity and agents that may cause a humoral immune response related to pancreatic cancer. Future studies could provide further insight into potential biological mechanisms by exploring longitudinal data such as repeated measurements of pre-diagnostic serum markers of the humoral immune system. Moreover, molecular pathological epidemiological studies, exploring tumor tissues, can potentially untangle the interlink between lifestyle factors, microbiome, carcinogenesis and the immune system (64-66).

\section{DATA AVAILABILITY STATEMENT}

Access to data for collaboration is provided by the Steering group members of the AMORIS study by request in email under the heading AMORIS Cohort Collaboration. This can be found at the AMORIS homepage http://amoriscohort.imm.ki.se.

\section{ETHICS STATEMENT}

This study complied with the Declaration of Helsinki and was approved by the Ethics Review Board of the Karolinska Institute who waived the need for consent.

\section{AUTHOR CONTRIBUTIONS}

SS, AS, NH, GW, and HG: data collection. SS, AS, DM, NH, GW, HG, LH, IJ, and MV: data analysis and interpretation. SS and AS: draft of manuscript. SS, DM, AS, DS, SK, DJ, NH, GW, HG, LH, IJ, and MV: final editing of manuscript. We can confirm that the manuscript has been read and approved by all named authors and that there are no other persons who satisfied the criteria for authorship but are not listed.

\section{FUNDING}

This work was supported by King's College London, Karolinska Institutet, Pancreatic Cancer Action and the Gunnar and IJ Foundation for Laboratory Medicine. The research was also supported by the National Institute for Health Research (NIHR) Biomedical Research Centre (BRC) based at Guy's and St Thomas' NHS Foundation Trust and King's College London (IS-BRC-1215-20006). The views expressed are those of the author(s) and not necessarily those of the NHS, the NIHR or the Department of Health. The authors acknowledge support by Cancer Research UK (C30122/A11527; C30122/A15774); The Academy of Medical Sciences; the Medical Research Council (MR/L023091/1); Cancer Research UK King's Health Partners Centre at King's College London; CRUK/NIHR in England/DoH for Scotland, Wales and Northern Ireland Experimental Cancer 
Medicine Centre (C10355/A15587). The funding sources had no role in the design of this study and collection, execution, analyses, interpretation of the data, writing the manuscript or decision to submit results.

\section{ACKNOWLEDGMENTS}

The authors are grateful to all sample and data donors who participated in the AMORIS study.

\section{REFERENCES}

1. Rahib L, Smith BD, Aizenberg R, Rosenzweig AB, Fleshman JM, Matrisian LM. Projecting cancer incidence and deaths to 2030: the unexpected Burden of thyroid, liver, and pancreas cancers in the Untied States. Cancer Res. (2014). 74:2913-21. doi: 10.1158/0008-5472.CAN-14-0155

2. Luo G, Zhang Y, Guo P, Ji H, Xiao Y, Li K. Global patterns and trends in pancreatic cancer incidence: age, period, and birth cohort analysis. Pancreas. (2019) 48:199-208. doi: 10.1097/MPA.0000000000001230

3. Lynch SM, Vrieling A, Lubin JH, Kraft P, Mendelsohn JB, Hartge P, et al. Cigarette smoking and pancreatic cancer: a pooled analysis from the pancreatic cancer cohort consortium. Am J Epidemiol. (2009) 170:403-13. doi: 10.1093/aje/kwp134

4. Ben Q, Xu M, Ning X, Liu J, Hong S, Huang W, et al. Diabetes mellitus and risk of pancreatic cancer: a meta-analysis of cohort studies. Eur J Cancer. (2011) 47:1928-37. doi: 10.1016/j.ejca.2011.03.003

5. Duell EJ, Lucenteforte E, Olson SH, Bracci PM, Li D, Risch HA, et al. Pancreatitis and pancreatic cancer risk: a pooled analysis in the International Pancreatic Cancer Case-Control Consortium (PanC4). Ann Oncol. (2012) 23:2964-70. doi: 10.1093/annonc/mds140

6. Ekbom A, Trichopoulos D. Pancreatic cancer. In: Adami HO, Hunter D, Trichopoulos D, editors. Textbook of Cander Epidemiology. New York, NY: Oxford University Press (2008). p. 333-48. doi: 10.1093/acprof:oso/9780195311174.003.0013

7. Ghaneh P, Costello E, Neoptolemos JP. Biology and management of pancreatic cancer. Gut. (2007) 56:1134-52. doi: 10.1136/gut.2006.113068

8. Michaud DS. Role of bacterial infections in pancreatic cancer. Carcinogenesis. (2013) 34:2193-7. doi: 10.1093/carcin/bgt249

9. Wang $\mathrm{C}$, Li J. Pathogenic microorganisms and pancreatic cancer. Gastrointestinal Tumors. (2015) 2:41-7. doi: 10.1159/0003 80896

10. Tomasiewicz K, Modrzewska R, Lyczak A, Krawczuk G. TT virus infection and pancreatic cancer: relationship or accidental coexistence. World J Gastroenterol. (2005) 11:2847. doi: 10.3748/wjg.v11.i18.2847

11. $\mathrm{Xu} \mathrm{JH}, \mathrm{Fu} J$ J, Wang XL, Zhu JY, Ye XH, Chen SD. Hepatitis $\mathrm{B}$ or $\mathrm{C}$ viral infection and risk of pancreatic cancer: a metaanalysis of observational studies. World J Gastroenterol. (2013) 19:4234-41. doi: 10.3748/wjg.v19.i26.4234

12. Wang Y, Yang S, Song F, Cao S, Yin X, Xie J, et al. Hepatitis B virus status and the risk of pancreatic cancer: a meta-analysis. Eur J Cancer Prev. (2013) 22:328-34. doi: 10.1097/CEJ.0b013e32835b6a21

13. Desai R, Patel U, Sharma S, Singh S, Doshi S, Shaheen S, et al. Association between hepatitis $B$ infection and pancreatic cancer: a population-based analysis in the United States. Pancreas. (2018) 47:84955. doi: 10.1097/MPA.0000000000001095

14. Schulte A, Pandeya N, Fawcett J, Fritschi L, Risch HA, Webb PM, et al. Association between Helicobacter pylori and pancreatic cancer risk: a meta-analysis. Cancer Causes Cont. (2015) 26:102735. doi: 10.1007/s10552-015-0595-3

15. Raderer M, Wrba F, Kornek G, Maca T, Koller DY, Weinlaender G, et al. Association between Helicobacter pylori infection and pancreatic cancer. Oncology. (1998) 55:16-9. doi: 10.1159/000011830

16. Stolzenberg-Solomon RZ, Blaser MJ, Limburg PJ, Perez-Perez G, Taylor PR, Virtamo J, et al. Helicobacter pylori seropositivity as a risk factor for pancreatic cancer. J Nat Cancer Inst. (2001) 93:937-41. doi: 10.1093/jnci/93.12.937

17. Xiao M, Wang Y, Gao Y. Association between Helicobacter pylori infection and pancreatic cancer development: a meta-analysis. PLoS ONE. (2013) 8:e75559. doi: 10.1371/journal.pone.0075559
18. Liu X-b, Gao Z-y, Sun C-t, Wen H, Gao B, Li S-b, et al. The potential role of $P$. gingivalis in gastrointestinal cancer: a mini review. Infect Agents Cancer. (2019) 14:23. doi: 10.1186/s13027-019-0239-4

19. Ahn J, Segers S, Hayes RB. Periodontal disease, Porphyromonqs gingivalis serum antibody levels and orodigestive cancer mortality. Carcinogenesis. (2012) 33:1055-8. doi: 10.1093/carcin/bgs112

20. Michaud DS, Izard J, Wilhelm-Benartzi CS, You DH, Grote VA, TjønnelA, et al. Plasma antibodies to oral bacteria and risk of pancreatic cancer in a large European prospective cohort study. Gut. (2013) 62:176470. doi: 10.1158/1538-7445.AM2012-LB-328

21. Hujoel PP, Drangsholt M, Spiekerman C, Weiss NS. An exploration of the Periodontotis-cancer association. Ann Epidemiol. (2003) 13:3126. doi: 10.1016/S1047-2797(02)00425-8

22. Michaud DS, Joshipura K, Giovannucci E, Fuchs CS. A prospective study of periodontal disease and pancreatic cancer in US male health professionals. $J$ Natl Cancer Inst. (2007) 99:171-5. doi: 10.1093/jnci/djk021

23. Mitsuhashi K, Nosho K, Sukawa Y, Matsunaga Y, Ito M, Kurihara $\mathrm{H}$, et al. Association of Fusobacterium species in pancreatic cancer tissues with molecular features and prognosis. Oncotarget. (2015) 6:720920. doi: 10.18632/oncotarget.3109

24. Michaud DS, Fu Z, Shi J, Chung M. Periodontal disease, tooth loss, and cancer risk. Epidemiol Rev. (2017) 39:49-58. doi: 10.1093/epirev/mxx006

25. Cotterchio M, Lowcock E, Hudson TJ, Greenwood C, Gallinger S. Association between allergies and risk of pancreatic cancer. Cancer Epidemiol Biomark Prev. (2014) 23:469-80. doi: 10.1158/1055-9965.EPI-13-0965

26. Merrill RM, Isakson RT, Beck RE. The association between allergies and cancer: what is currently known? Ann Allergy Asthma Immunol. (2007) 99:102-17. doi: 10.1016/S1081-1206(10)60632-1

27. Turner MC, Chen Y, Krewski D, Ghadirian P. An overview of the association between allergy and cancer. Int J Cancer. (2006) 118:312432. doi: $10.1002 /$ ijc. 21752

28. Wulaningsih W, Holmberg L, Garmo H, Karagiannis SN, Ahlstedt S, Malmstrom $\mathrm{H}$, et al. Investigating the association between allergen-specific immunoglobulin E, cancer risk and survival. Oncoimmunology. (2016) 5:e1154250. doi: 10.1080/2162402X.2016.1154250

29. Gandini S, Lowenfels AB, Jaffee EM, Armstrong TD, Maisonneuve P. Allergies and the risk of pancreatic cancer: a meta-analysis with review of epidemiology and biological mechanisms. Cancer Epidemiol Biomark Prev. (2005) 14:190816. doi: 10.1158/1055-9965.EPI-05-0119

30. Ingvarsson J, Wingren C, Carlsson A, Ellmark P, Wahren B, Engström $\mathrm{G}$, et al. Detection of pancreatic cancer using antibody microarray-based serum protein profiling. Proteomics. (2008) 8:2211-9. doi: 10.1002/pmic.2007 01167

31. Orchekowski R, Hamelinck D, Li L, Gliwa E, VanBrocklin M, Marrero JA, et al. Antibody microarray profiling reveals individual and combined serum proteins associated with pancreatic cancer. Cancer Res. (2005) 65:11193202. doi: 10.1158/0008-5472.CAN-05-1436

32. Kamisawa T, Chen PY, Tu Y, Nakajima H, Egawa N, Tsuruta K, et al. Pancreatic cancer with a high serum IgG4 concentration. World J Gastroenterol. (2006) 12:6225. doi: 10.3748/wjg.v12.i38.6225

33. Kotera Y, Fontenot JD, Pecher G, Metzgar RS, Finn OJ. Humoral immunity against a tandem repeat epitope of human mucin MUC-1 in sera from breast, pancreatic, and colon cancer patients. Cancer Res. (1994) 54:2856-60.

34. Talar-Wojnarowska R, Gasiorowska A, Olakowski M, Dranka-Bojarowska D, Lampe P, Smigielski J, et al. Utility of serum IgG, IgG4 and carbonic anhydrase II antibodies in distinguishing autoimmune pancreatitis from pancreatic cancer and chronic pancreatitis. Adv Med Sci. (2014) 59:28892. doi: 10.1016/j.advms.2014.08.003 
35. Walldius G, Malmström H, Jungner I, de Faire U, Lambe M, Van Hemelrijck M, et al. Cohort profile: the AMORIS cohort. Int J Epidemiol. (2017) 46:11031103i. doi: 10.1093/ije/dyw333

36. Walldius G, Jungner I, Holme I, Aastveit AH, Kolar W, Steiner E. High apolipoprotein B, low apolipoprotein A-I and improvement in the prediction of fatal myocardial infarction (AMORIS study):a prospective study. Lancet. (2001) 358:2026-33. doi: 10.1016/S0140-6736(01)07098-2

37. Holme I, Aastveit AH, Jungner I, Walldius G. Relationships between lipoprotein components and risk of myocardial infarction: age, gender and short versus longer follow-up periods in the Apolipoprotein MOrtality RISk study (AMORIS). J Int Med. (2008) 264:30-8. doi: 10.1111/j.1365-2796.2008.01925.x

38. Holme I, Aastveit AH, Hammar N, Jungner I, Walldius G. Relationships between lipoprotein components and risk of ischaemic and haemorrhagic stroke in the Apolipoprotein MOrtality RISk study (AMORIS). J Int Med. (2009) 265:275-87. doi: 10.1111/j.1365-2796.2008.02016.x

39. Walldius G, Jungner I, Kolar W, Holme I, Steiner E. High cholesterol and triglyceride values in Swedish males and females: increased risk of fatal myocardial infarction. First report from the AMORIS (Apolipoprotein related MOrtality RISk) study. Blood Pres Suppl. (1992) 4:35-42.

40. Junger I, Kolar W. CALAB. S-Immunoglobulin A (1994).

41. Junger I, Kolar W. CALAB. S-Immunoglobulin G (1994).

42. Junger I, Kolar W. CALAB. S-Immunoglobulin M (1994).

43. Gonzalez-Quintela A, Alende R, Gude F, Campos J, Rey J, Meijide LM, et al. Serum levels of immunoglobulins (IgG, IgA, IgM) in a general adult population and their relationship with alcohol consumption, smoking and common metabolic abnormalities. Clin Exp Immunol. (2007) 151:4250. doi: 10.1111/j.1365-2249.2007.03545.x

44. Wians FH. Normal laboratory values: blood, plasma, and serum. MSD Manual. (2018).

45. Desquilbet L, Mariotti F. Dose-response analyses using restricted cubic spline functions in public health research. Stat Med. (2010) 29:103757. doi: $10.1002 / \mathrm{sim} .3841$

46. Grote VA, Kaaks R, Nieters A, TjønnelA, Halkjær J, Overvad K, et al. Inflammation marker and risk of pancreatic cancer: a nested casecontrol study within the EPIC cohort. Br J Cancer. (2012) 106:1866-74. doi: $10.1038 /$ bjc. 2012.172

47. Andersen DK, Andren-Sandberg A, Duell EJ, Goggins M, Korc M, Petersen GM, et al. Pancreatitis-diabetes-pancreatic cancer: summary of an NIDDK-NCI workshop. Pancreas. (2013) 42:1227-37. doi: 10.1097/MPA.0b013e3182a9ad9d

48. Raimondi S, Lowenfels AB, Morselli-Labate AM, Maisonneuve P, Pezzilli R. Pancreatic cancer in chronic pancreatitis; aetiology, incidence, and early detection. Best Pract Res Clin Gastroenterol. (2010) 24:349-58. doi: 10.1016/j.bpg.2010.02.007

49. Michaud DS, Izard J. Microbiota, oral microbiome, and pancreatic cancer. Cancer J. (2014) 20:203-6. doi: 10.1097/PPO.0000000000000046

50. Inman KS, Francis AA, Murray NR. Complex role for the immune system in initiation and progression of pancreatic cancer. Wotld J Gastroenterol. (2014) 20:11160-81. doi: 10.3748/wjg.v20.i32.11160

51. Roghanian A, Fraser C, Kleyman M, Chen J. B cells promote pancreatic tumorigenesis. Cancer Discov. (2016) 6:2302. doi: 10.1158/2159-8290.CD-16-0100

52. Tanaka M, Komatsu N, Yanagimoto $Y$, Oka M, Shichijo S, Okuda $\mathrm{S}$, et al. Development of a new diagnostic tool for pancreatic cancer: simultaneous measurement of antibodies against peptides recognized by cytotoxic $\mathrm{T}$ lymphocytes. Kurume Med J. (2006). 53:63-70. doi: 10.2739/kurumemedj.53.63

53. Archibugi L, Signoretti M, Capurso G. The microbiome and pancreatic cancer: an evidence-based association? Clin Gastroenterol. (2018) 52:S825. doi: 10.1097/MCG.0000000000001092
54. Wei M-Y, Shi S, Liang C, Meng Q-C, Hua J, Zhang Y-Y, et al. The microbiota and microbiome in pancreatic cancer: more influential than expected. $\mathrm{Mol}$ Cancer. (2019) 18:97. doi: 10.1186/s12943-019-1008-0

55. Kau AL, Ahern PP, Griffin NW, Goodman AL, Gordon JI. Human nutrition, the gut microbiome and the immune system. Nature. (2011) 474:327. doi: 10.1038/nature10213

56. Shen J, Obin MS, Zhao L. The gut microbiota, obesity and insulin resistance. Mol Aspects Med. (2013) 34:39-58. doi: 10.1016/j.mam.2012.11.001

57. Qin J, Li Y, Cai Z, Li S, Zhu J, Zhang F, et al. A metagenome-wide association study of gut microbiota in type 2 diabetes. Nature. (2012) 490:55. doi: 10.1038/nature 11450

58. Fox JG, Feng Y, Theve EJ, Raczynski AR, Fiala JL, Doernte AL, et al. Gut microbes define liver cancer risk in mice exposed to chemical and viral transgenic hepatocarcinogens. Gut. (2010) 59:8897. doi: 10.1136/gut.2009.183749

59. Hamanaka Y, Suehiro Y, Fukui M, Shikichi K, Imai K, Hinoda Y. Circulating anti-MUC1 IgG antibodies as a favorable prognostic factor for pancreatic cancer. Int J Cancer. (2003) 103:97-100. doi: 10.1002/ijc.10801

60. Follia L, Ferrero G, Mandili G, Beccuti M, Giordano D, Spadi R, et al. Integrative analysis of novel metabolic subtypes in pancreatic cancer fosters new prognostic biomarkers. Front Oncol. (2019) 9:115. doi: 10.3389/fonc.2019.00115

61. Holme I, Aastveit AH, Hammar N, Jungner I, Walldius G. Inflammatory markers, lipoprotein components and risk of major cardiovascular events in 65,005 men and women in the Apolipoprotein MOrtality RISk study (AMORIS). Atherosclerosis. (2013) 213:299-305. doi: 10.1016/j.atherosclerosis.2010.08.049

62. Wulaningsih W, Michaelsson K, Garmo H, Hammar N, Jungner I, Walldius G, et al. Serum calcium and risk of gastrointestinal cancer in the Swedish AMORIS study. BMC Public Health. (2013) 13:663. doi: 10.1186/1471-2407-13-257

63. Fu SL, Pierre J, Smith-Norowitz TA, Hagler M, Bowne W, Pincus MR, et al. Immunoglobulin $\mathrm{E}$ antibodies from pancreatic cancer patients mediate antibody-dependent cell-mediated cytotoxicity against pancreatic cancer cells. Clin Exp Immunol. (2008) 153:401-9. doi: 10.1111/j.1365-2249.2008.03 726.x

64. Ogino S, Nowak JA, Hamada T DAM Jr, Nishihara R. Insights into pathogenic interactions among environment, host, and tumor at the crossroads of molecular pathology and epidemiology. Annu Rev Pathol Mech Dis. (2019) 14:83-103. doi: 10.1146/annurev-pathmechdis-012418-012818

65. Hamada T, Nowak JA, Milner DA Jr, Song M, Ogino S. Integration of microbiology, molecular pathology, and epidemiology: a new paradigm to explore the pathogenesis of microbiome-driven neoplasms. J Pathol. (2019) 247:615-28. doi: 10.1002/path.5236

66. Ogino S, Nowak JA, Hamada T, Phipps AI, Peters U, Milner $\mathrm{DA} \mathrm{Jr}$, et al. Integrative analysis of exogenous, endogenous, tumour and immune factors for precision medicine. Gut. (2018) 67:1168-80. doi: 10.1136/gutjnl-2017-315537

Conflict of Interest: The authors declare that the research was conducted in the absence of any commercial or financial relationships that could be construed as a potential conflict of interest.

Copyright (C) 2020 Sollie, Santaolalla, Michaud, Sarker, Karagiannis, Josephs, Hammar, Walldius, Garmo, Holmberg, Jungner and Van Hemelrijck. This is an open-access article distributed under the terms of the Creative Commons Attribution License (CC BY). The use, distribution or reproduction in other forums is permitted, provided the original author(s) and the copyright owner(s) are credited and that the original publication in this journal is cited, in accordance with accepted academic practice. No use, distribution or reproduction is permitted which does not comply with these terms. 